\title{
Aplikasi Pemetaan Gedung Berbasis Web dengan Framework Laravel (Studi Kasus : PT. Bank BRI Syariah)
}

\author{
SEPTIAN EKA ADY BUANANTA ${ }^{1}$
}

${ }^{1}$ Universitas Mercubuana

Email : adyseptian48@gmail.com

\begin{abstract}
ABSTRAK
PT. Bank BRI Syariah menyadari betapa pentingnya mengikuti perkembangan teknologi dalam hal mengoptimalkan penyimpanan, pengolahan dan presentasi data dalam bentuk digital. Salah satu contohnya adalah proses pemetaan denah gedung yang dimiliki oleh PT. Bank BRI Syariah. Dengan adanya pemetaan denah dalam bentuk digital dapat memberikan fleksibilitas dari segi pengaksesan dan penyajian informasi yang sangat efektif. Dalam menjawab hal tersebut, maka dibangunlah aplikasi pemetaan gedung yang merupakan web based application. Aplikasi pemetaan gedung ini dibangun dengan menggunakan PHP dengan framework Laravel. Database yang digunakan adalah MySQL. Software penghubung antara aplikasi dan database adalah webserver Xampp. Dalam proses pemodelan perancangan sistem informasi ini, menggunakan model prototype yang digambarkan dengan Unified Modelling Language (UML).
\end{abstract}

Kata kunci: Aplikasi, Pemetaan, Gedung, Web, Laravel.

\begin{abstract}
PT. Bank BRI Syariah realizes how important it is to keep up with technological developments in terms of optimizing the storage, processing and presentation of data in digital form. One example is the mapping process of building plans owned by PT. Bank BRI Syariah. The existence of floor plans in digital form can provide flexibility in terms of accessing and presenting information that is very effective. In answering this, a building mapping application was built which is a web based application. This building mapping application was built using PHP with Laravel framework. The database used is MySQL. The connecting software between the application and database is the Xampp webserver. In the process of modeling this information system design, using a prototype model which is described by the Unified Modeling Language (UML).
\end{abstract}

Keywords: Application, Mapping, Building, Web, Laravel 


\section{PENDAHULUAN}

Proses pemetaan dan pendataan gedung selama ini masih belum terdokumentasi dengan baik dan rapi, membuat suatu perusahaan harus mengikuti perkembangan teknologi yang terjadi. Pada kenyataannya hampir semua kegiatan perusahaan menggunakan fasilitas komputer sebagai penunjang teknologi dalam menjalankan kegiatan operasional mereka sehari-hari. Ada yang menggunakan fasilitas komputer secara total dengan sistem yang terotomatisasi dan ada juga yang menggunakan hanya sebagian saja yaitu hanya di beberapa bagian operasional saja. Dengan menggunakan teknologi yang semakin berkembang, didapatkan efisiensi waktu sehingga kinerja perusahaan bisa lebih optimal.

PT. Bank BRI Syariah yang tersebar diseluruh Indonesia menyadari betapa pentingnya mengikuti perkembangan teknologi dalam hal mengoptimalkan penyimpanan, pengolahan dan presentasi data dalam bentuk digital. Salah satu contohnya adalah proses pemetaan letak dan denah gedung yang dimiliki oleh PT. Bank BRI Syariah. Dengan adanya pemetaan letak gedung dan denah dalam bentuk digital dapat memberikan fleksibilitas dari segi pengaksesan dan penyajian informasi yang sangat efektif. Selain itu tidak semua gedung PT. Bank BRI Syariah merupakan milik sendiri, tetapi juga ada yang berstatus sewa. Untuk gedung-gedung yang berstatus sewa dibutuhkan suatu alat pengingat kapan waktu berakhirnya sewa dan ketika datangnya waktu pembayaran untuk membayar sewa.

Berdasarkan permasalahan pada PT. Bank BRI Syariah membutuhkan Aplikasi Pemetaan Gedung agar semua kegiatan operasional dapat berjalan ke arah yang lebih baik. Aplikasi Pemetaan Gedung bertanggung jawab untuk menyediakan informasi mengenai pemetaan letak gedung, data gedung, denah setiap lantai, data area yang ada di gedung tersebut serta untuk gedung yang statusnya sewa dapat menampilkan notifikasi waktu berakhirnya sewa, waktu pembayaran dan jumlah tagihan yang harus dibayar.

\section{TINJAUAN PUSTAKA}

\subsection{Definisi Pemetaan}

Menurut Kamus Besar Bahasa Indonesia (KBBI) arti dari pemetaan adalah pe.me.ta.an nomina (kata benda) proses, cara, perbuatan membuat peta. Peta /pe.ta/ $\mathrm{n}$ adalah gambar atau lukisan pada kertas dan sebagainya yang menunjukkan letak tanah, laut, sungai, gunung, dan sebagainya; representasi melalui gambar dari suatu daerah yang menyatakan sifat, seperti batas daerah, sifat permukaan; denah.

\subsection{Web Framework}

Web Framework merupakan kumpulan skrip terutama class dan function yang dapat mempermudah pengguna dalam membangun aplikasi berbasis web untuk mendukung pengembangan web secara dinamis. Framework merupakan komponen yang sudah diatur sedemikian rupa sehingga saat digunakan tidak perlu menulis program dari awal karena sudah disediakan oleh framework dan hanya perlu untuk dipanggil. Web Framework bekerja menggunakan pola Model-View-Controller (MVC), yaitu pola arsitektur yang memisahkan aplikasi menjadi tiga komponen utama model, view, dan controller.

1) Model, komponen ini berhubungan dengan semua data yang menggunakan logika pengguna yang dapat menampilkan data yang ditransferkan antara komponen view dan controller. 
2) View, komponen ini digunakan untuk semua logika aplikasi untuk user interface.

3) Controller, komponen ini bekerja sebagai antarmuka antara komponen view dan model untuk memproses semua logika dan permintaan, manipulasi data menggunakan komponen model dan interaksi dengan view untuk diarahkan ke output akhir.

\subsection{Framework Laravel}

Laravel adalah sebuah framework PHP yang dirilis dibawah lisensi MIT, dibangun dengan konsep MVC (model view controller). Laravel adalah pengembangan website berbasis MVP yang ditulis dalam PHP yang dirancang untuk meningkatkan kualitas perangkat lunak dengan mengurangi biaya pengembangan awal dan biaya pemeliharaan, dan untuk meningkatkan pengalaman bekerja dengan aplikasi dengan menyediakan sintaks yang ekspresif, jelas dan menghemat waktu.

MVC adalah sebuah pendekatan perangkat lunak yang memisahkan aplikasi logika dari presentasi. MVC memisahkan aplikasi berdasarkan komponen- komponen aplikasi, seperti : manipulasi data, controller, dan user interface.

1. Model, Model mewakili struktur data. Biasanya model berisi fungsi-fungsi yang membantu seseorang dalam pengelolaan basis data seperti memasukkan data ke basis data, pembaruan data dan lain-lain.

2. View, View adalah bagian yang mengatur tampilan ke pengguna. Bisa dikatakan berupa halaman web.

3. Controller, Controller merupakan bagian yang menjembatani model dan view.

Beberapa fitur yang terdapat di Laravel :

- Bundles, yaitu sebuah fitur dengan sistem pengemasan modular dan tersedia beragam di aplikasi.

- Eloquent ORM, merupakan penerapan PHP lanjutan menyediakan metode internal dari pola "active record" yang menagatasi masalah pada hubungan objek database.

- Application Logic, merupakan bagian dari aplikasi, menggunakan controller atau bagian Route.

- Reverse Routing, mendefinisikan relasi atau hubungan antara Link dan Route.

- Restful controllers, memisahkan logika dalam melayani HTTP GET and POST.

- Class Auto Loading, menyediakan loading otomatis untuk class PHP.

- View Composer, adalah kode unit logikal yang dapat dieksekusi ketika view sedang loading.

- IoC Container, memungkin obyek baru dihasilkan dengan pembalikan controller.

- Migration, menyediakan sistem kontrol untuk skema database.

- Unit Testing, banyak tes untuk mendeteksi dan mencegah regresi.

- Automatic Pagination, menyederhanakan tugas dari penerapan halaman.

\subsection{MySQL}

MySQL merupakan open source relational database management system (RDBMS), pada Juli 2013 merupakan urutan kedua yang secara luas menggunakan RDBMS dan paling luas yang menggunakan model open source server klien RDBMS. Nama MySQL merupakan kombinasi dari "My" yang merupakan nama putri dari 
pendiri Michael Widenius dan "SQL" yang merupakan singkatan dari Structured Query Language. MySQL dimiliki dan disponsori oleh perusahaan Swedia MySQL AB yang sekarang dimiliki oleh Oracle Corporation. Sebagai jasa kepemilikan MySQL tersedia dalam edisi berbayar yang memberikan tambahan fungsional.

\section{PEMBAHASAN}

\subsection{Analisis Kelemahan Sistem}

Penulis menggunakan framework PIECES untuk melakukan analysis Kelemahan Sistem yang Sedang Berjalan, hasil analisis dapat dirumuskan kelemahan sistem sebagai berikut :

\section{Performance}

Kelemahan sistem lama:

Proses pengecekan area yang kosong dan terisi masih manual, yaitu pihak manajemen harus datang langsung ke lokasi. Selain itu manajemen PT. Bank BRI Syariah tidak memiliki pemetaan mengenai lokasi setiap gedung kantor PT. Bank BRI Syariah. Dalam proses pengecekan berakhirnya masa sewa dan pembayaran juga masih dilakukan secara manual.

Sistem yang diajukan :

Aplikasi Pemetaan Gedung dengan pemanfaatan perangkat lunak khusus yang menangani proses pengelolaaan data seperti insert, update, delete dan menggunakan database dalam pencarian data seperti data Gedung dan data sewa, sehingga dapat secara otomatis memberikan notifikasi perihal berakhirnya masa sewa dan waktu pembayaran. Selain itu dapat menampilkan pemetaan letak area tiap lantai pada gedung.

2. Information

Kelemahan sistem lama:

Informasi berakhirnya masa sewa dan waktu pembayaran disampaikan secara langsung kepada pihak manajemen PT. Bank BRI Syariah melalui surat atau email, sehingga Manajemen PT. Bank BRI Syariah harus mengecek secara manual gedung mana yang masa sewanya akan habis ataupun sudah jatuh tempo waktu pembayarannya. Penyajian data denah masih dalam bentuk autocad sehingga tidak ada koneksi antara data dengan area yang ditempatinya.

Sistem yang diajukan :

Aplikasi Pemetaan Gedung yang dapat memberikan notifikasi berakhirnya masa sewa secara otomatis dalam waktu 3 bulan sebelumnya dan memberikan notifikasi pembayaran bagi gedung yang sudah jatuh tempo waktu pembayarannya. Selain itu menampilkan pemetaan area, sehingga dapat menampilkan area mana yang masih kosong ataupun sudah terisi.

3. Economic

Kelemahan sistem lama:

Dibutuhkan biaya untuk melakukan pengecekan area karena harus datang langsung ke lokasi.

Sistem yang diajukan :

Dalam jangka waktu yang panjang Aplikasi Pemetaan Gedung dapat menghemat biaya terutama dalam masalah survey, karena dengan adanya Aplikasi Pemetaan Gedung pihak manajemen tidak perlu datang langsung ke lokasi untuk melihat area yang masih kosong. 
Aplikasi Pemetaan Gedung Berbasis Web dengan Framework Laravel (Studi Kasus : PT. Bank BRI Syariah)

4. Control

Kelemahan sistem lama:

Pengontrolan terhadap gedung yang sewa dan pembayaran sulit dilakukan karena belum adanya notifikasi secara otomatis yang menampilkan gedung yang akan habis masa sewanya dan waktu pembayarannya.

Sistem yang diajukan :

Aplikasi Pemetaan Gedung yang dapat secara otomatis memberikan notifikasi berakhirya masa sewa dan waktu pembayaran.

5. Efficiency

Kelemahan sistem lama:

Data Denah dalam bentuk autocad yang masih terpisah dengan data gedung nya menyulitkan pihak manajemen untuk mengecek area mana yang masih kosong. Sistem yang diajukan :

Menampilkan pemetaan denah untuk tiap area sehingga memudahkan untuk mengidentifikasi area mana yang masih kosong.

6. Service

Kelemahan sistem lama:

Pihak Manajemen terkadang tidak mengetahui ataupun lupa kapan masa sewa nya akan habis dan kapan harus membayar karena belum adanya sistem yang otomatis memberikan notifikasi berakhirnya masa sewa dan waktu pembayaran.

Sistem yang diajukan :

Aplikasi Pemetaan Gedung yang secara otomatis memberikan notifikasi berakhirnya masa sewa dan waktu pembayaran.

\subsection{Pemodelan}

Pada tahap ini, semua hasil analisa kebutuhan pengguna dan kebutuhan sistem didefinisikan dalam bentuk diagram UML. Penulis menggunakan usecase diagram untuk mendefinisikan aktivitas-aktivitas pengguna sistem dan interaksi antara pengguna dengan sistem maupun interaksi antar pengguna. Usecase diagram aplikasi pemetaan gedung dapat dilihat pada Gambar 1.

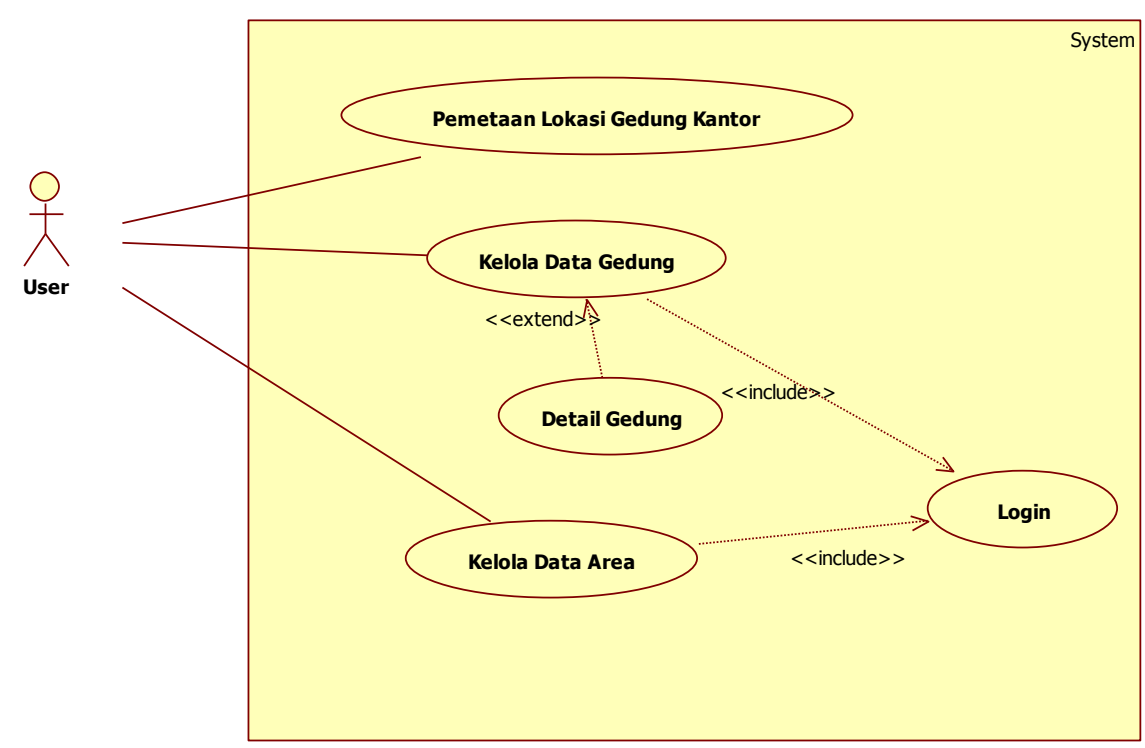

Gambar 1 Usecase Diagram 


\subsection{Hasil}

Dibawah ini merupakan hasil impelemtasi perancangan aplikasi pemetaan gedung. Tampilan awal aplikasi pemetaan gedung menggambarkan seluruh lokasi kantor PT. Bank BRI Syariah yang ada di Indonesia. Tampilan awal dapat dilhat pada gambar 2.

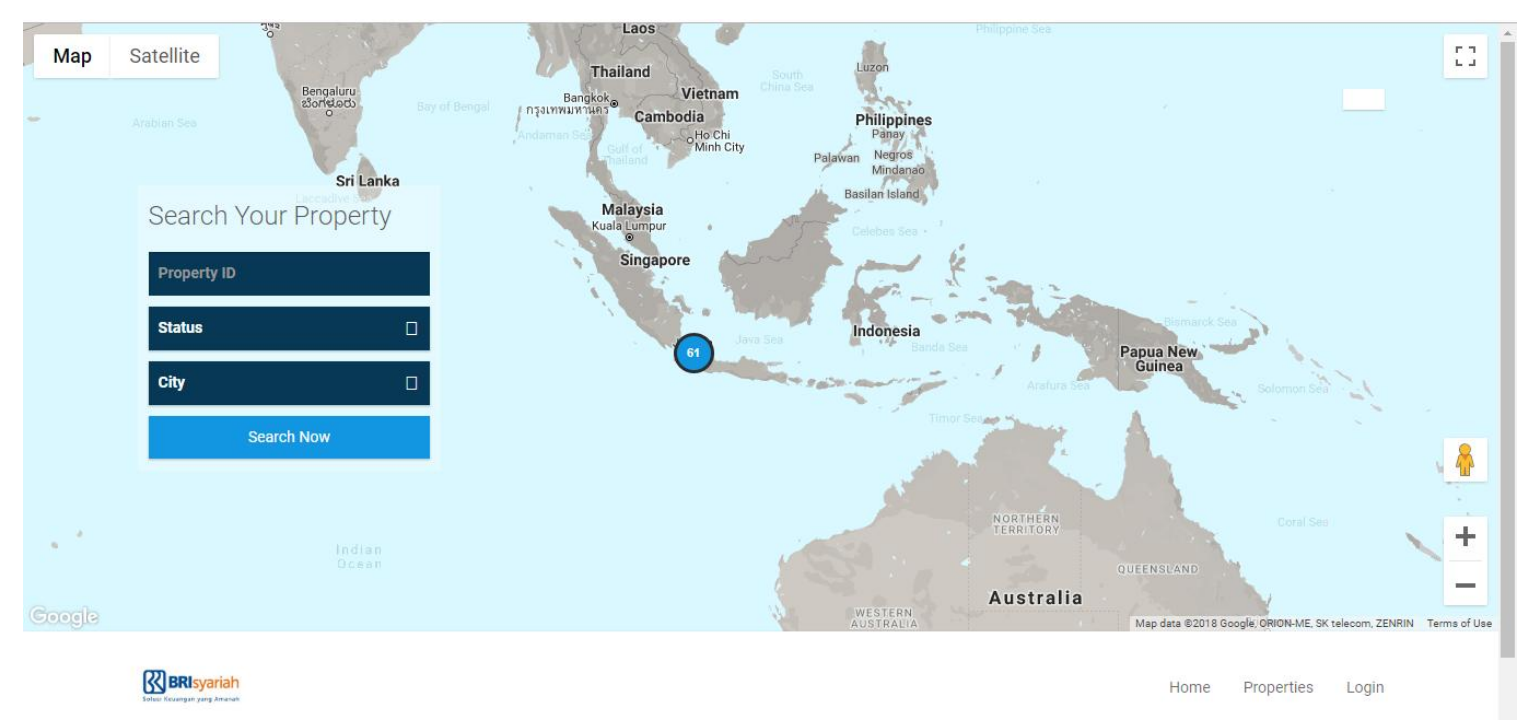

Gambar 2 Halaman Awal Aplikasi Pemetaan Gedung

Untuk setiap lokasi kantor dapat dilihat alamat detailnya dan gambar penampakan gedungnya seperti pada gambar 3 .

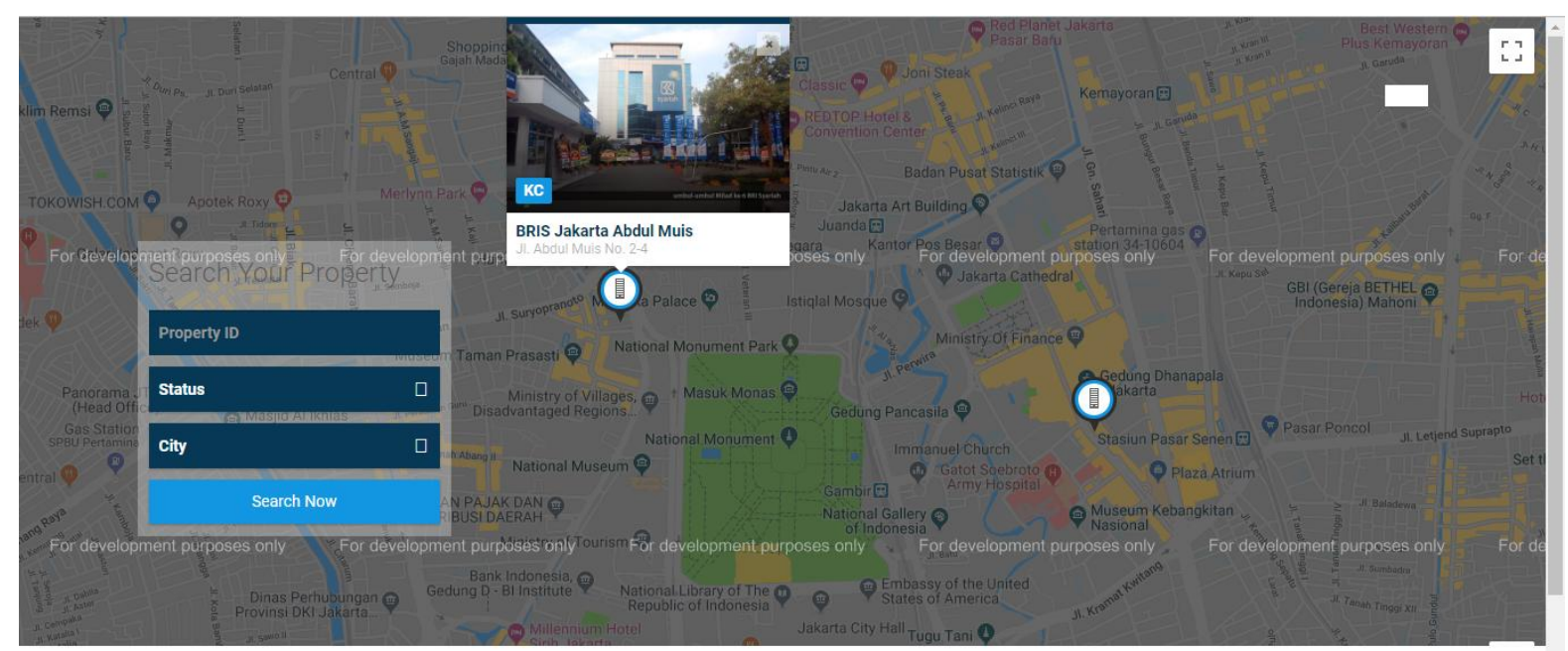

खBBRIsyariah

Gambar 3 Detail Lokasi Kantor 
Aplikasi Pemetaan Gedung Berbasis Web dengan Framework Laravel (Studi Kasus : PT. Bank BRI Syariah)

Untuk setiap gedung dapat dilihat denah nya seperti pada gambar 4.

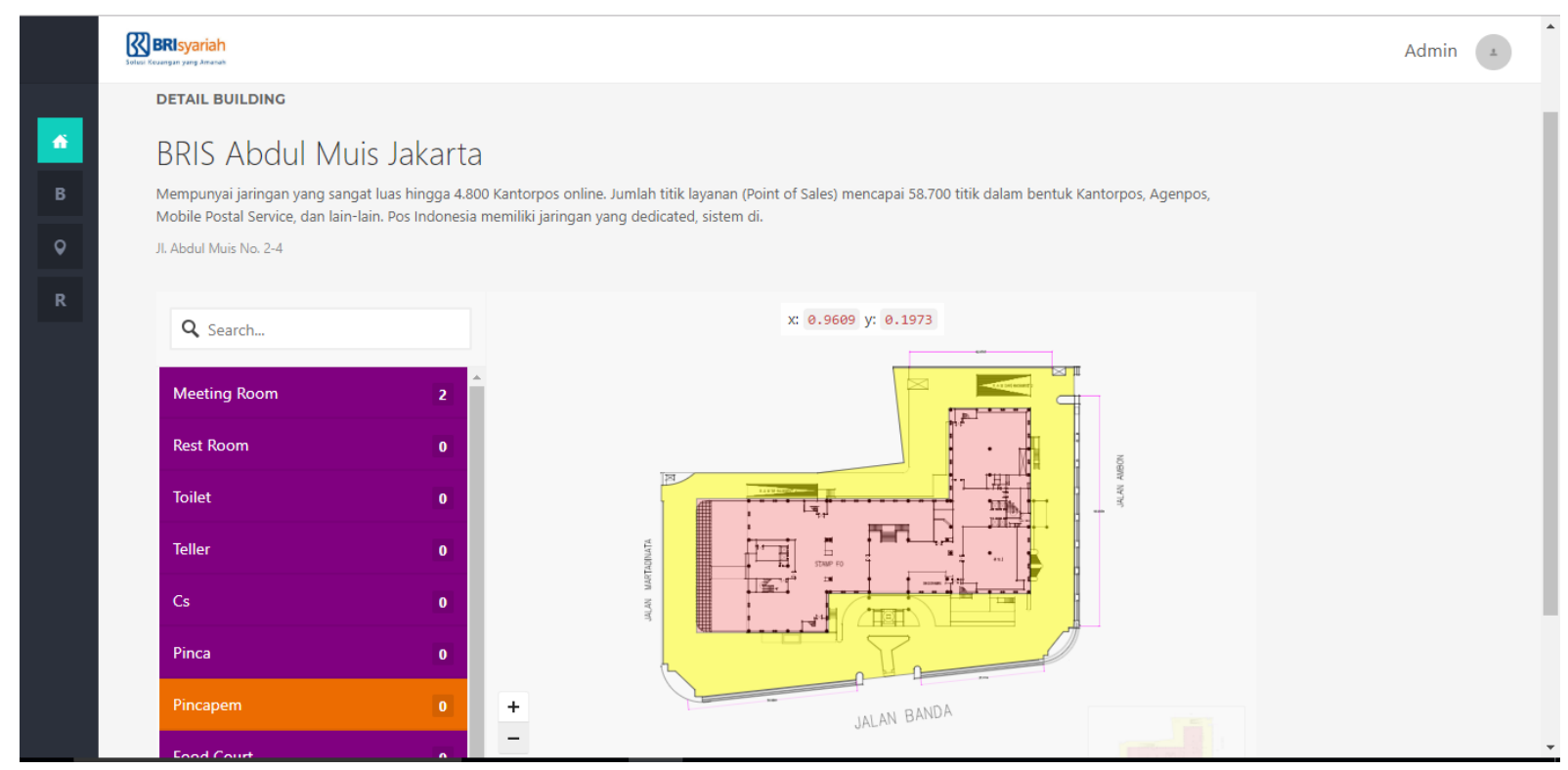

Gambar 4 Denah Gedung

Tiap area pada gedung dapat dilihat area mana yang sudah ditempati dan area mana yang masih kosong seperti pada gambar 5.

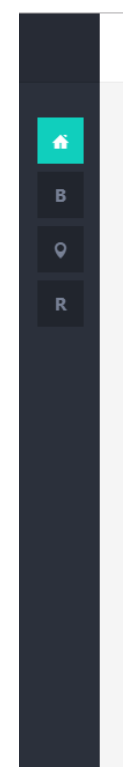

खBRlsyariah

Admin 2

\section{+ Add Floor}

Q Search...
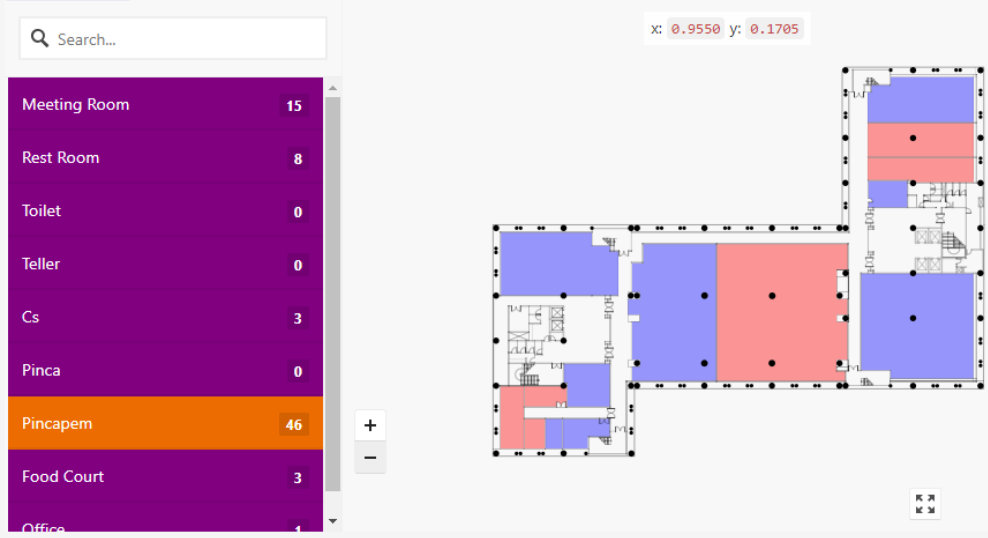

Gambar 5 Area dalam Gedung 
Setiap area dapat menampilkan detail informasi dari area tersebut seperti pada gambar 6 .

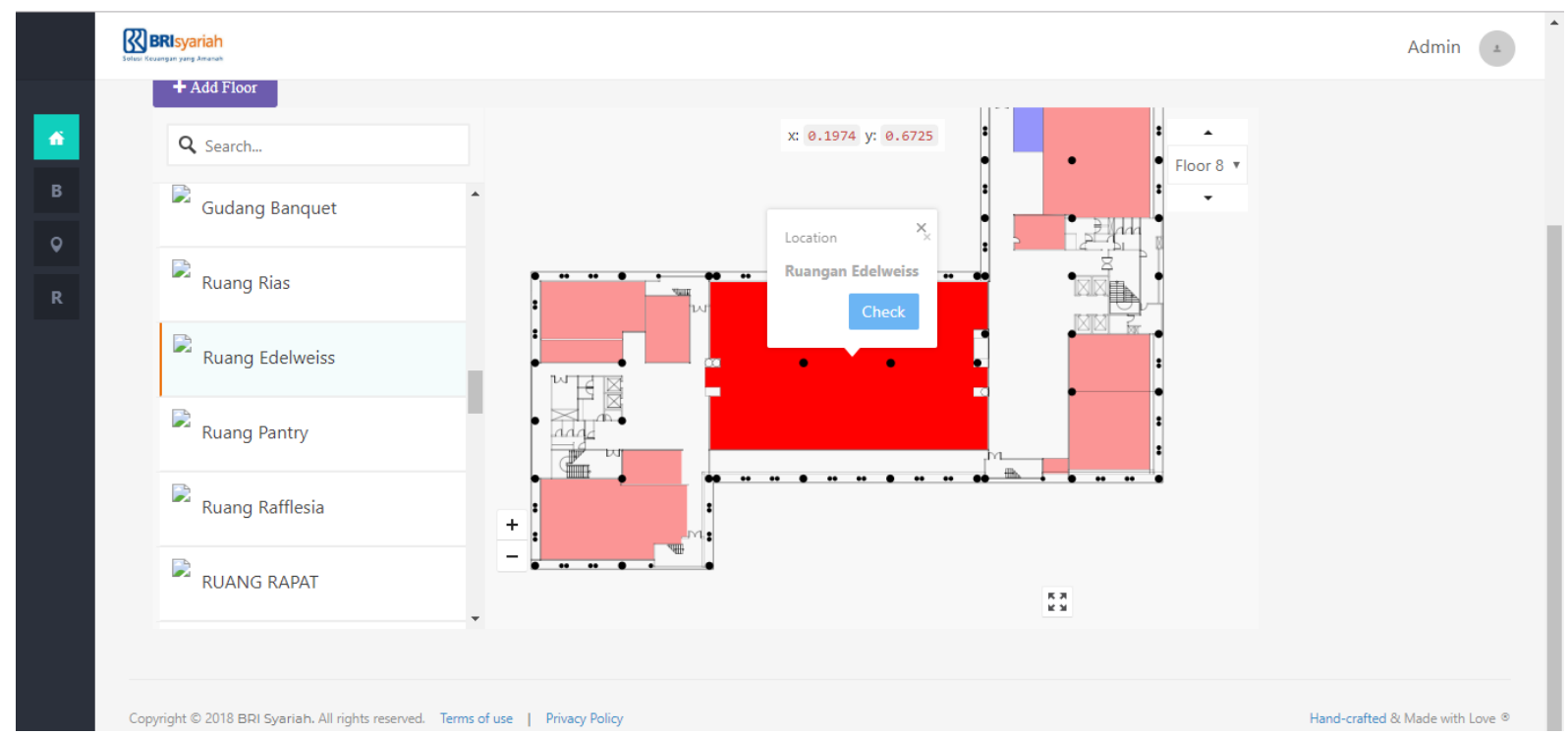

Gambar 6 Detail Area

\section{KESIMPULAN}

Dari hasil analisis dan perancangan serta implementasi "Aplikasi Pemetaan Gedung Berbasis Web dengan Framework Laravel (Studi Kasus : Bank BRI Syariah)" maka dapat disimpulkan beberapa poin sebagai berikut :

1. Aplikasi Pemetaan Gedung dapat menggambarkan letak gedung PT. Bank BRI Syariah se-Indonesia

2. Aplikasi Pemetaan Gedung dapat mengelola data gedung beserta denahnya.

3. Aplikasi Pemetaan Gedung dapat menampilkan penempatan pada tiap area sehingga memudahkan pihak manajemen dalam mengontrol area mana yang masih kosong ataupun mencari letak dari divisi tertentu.

4. Aplikasi Pemetaan Gedung dapat menampilkan notifikasi waktu berakhirnya sewa, waktu pembayaran dan jumlah tagihan untuk gedung-gedung yang berstatus sewa sehingga mengingatkan pihak manajemen untuk memperpanjang sewa dan membayar sewa.

\section{UCAPAN TERIMA KASIH}

Terima Kasih Penulis ucapkan kepada Bapak Handrie Noprisson, ST, M. Kom selaku Ketua Program Studi Sistem Informasi, Ibu Inge Handriani, M.ak, MMSI selaku Koordinator Tugas Akhir, Ibu Sarwati Rahayu, ST. MMSI selaku dosen pembimbing Tugas Akhir, Bapak Riad Sahara, S.SI., MT selaku dosen pembimbing akademik, Kedua Orang Tua Saya, Renaldy Dwi Hartanto Buananta selaku Adik Kandung Saya, Rekan-rekan sejawat senasib seperjuangan, serta Atasan dan rekan-rekan kerja di BRI Syariah yang sudah mensupport saya. 
Aplikasi Pemetaan Gedung Berbasis Web dengan Framework Laravel (Studi Kasus : PT. Bank BRI Syariah)

\section{DAFTAR RUJUKAN}

Febrian J. (2004) Kamus Pengetahuan Komputer dan Teknologi Informasi. Bandung: Informatika.

Lani Sidharta. (1995). Pengantar Sistem Informasi Bisnis, P.T. ELEX Media Komputindo, Jakarta.

Muhyuzir T.D. (2001). Analisa Perancangan Sistem Pengolahan Data, Cetakan Kedua, PT. Elex Media Komputindo, Jakarta.

O'Brein, James A. (2005). "Pengantar Sistem Informasi", Penerbit : Salemba 4, Jakarta.2005. Jogianto2 HM. Sistem Teknologi Informasi. Andi. Yogyakarta.2005.

S. Pressman, Ph. D, Roger diterjemahkan oleh L.N. Harnaningrum. (2002) Rekayasa Perangkat Lunak. Yogyakarta: ANDI.

Sommerville, Ian. (2003). Software Engineering (Rekayasa perangkat Lunak). Jakarta : Erlangga. 